\title{
Morphological, genetic and symbiotic characterization of root nodule bacteria isolated from Bambara groundnuts (Vigna subterran€ L . Verdc) from soils of LakeVictoria basin, western Kenya
}

\author{
Onyango Benson ${ }^{1,2,3^{*}}$, Anyango Beatrice ${ }^{2}$, Nyunja Regina ${ }^{2}$, P. K. Koech ${ }^{1}$, Robert A. Skilton ${ }^{3,4}$, Stomeo Francesca ${ }^{3}$ \\ ${ }^{1}$ Department of Biological Sciences, Chuka University, P. O. Box 109-40600, Chuka, Kenya. ${ }^{2}$ School of Biological and Physical Sciences, Jaramogi Oginga \\ Odinga University of Science and Technology, P. O. Box 210-40601, Bondo. ${ }^{3}$ Biosciences Eastern and Central Africa - International Livestock Research \\ Institute (BecA-ILRI) Hub, P.O. Box 30709-00100, Nairobi, Kenya. ${ }^{4}$ African Insect Science for Food and Health, P. O. Box 30772-00100, Nairobi, Kenya.
}

\section{ARTICLE INFO}

Article history:

Received on: 14/10/2014

Revised on: 07/11/2014

Accepted on: 22/12/2014

Available online: 27/02/2015

Key words:

Bambara groundnut, root nodule bacteria, 16 rRNA genes, symbiotic efficiency.

\begin{abstract}
Low soil nitrogen $(\mathrm{N})$ is a major constraint for sustainable crop production in smallholder farming systems in Africa. Grain legumes such as bambara groundnuts (Vigna subterranea $\mathrm{L}$. Verdc). can form $\mathrm{N}$ fixing symbiotic association with root nodule bacteria collectively called 'rhizobia'; in a process that can supply sufficient $\mathrm{N}$ for the legume and other crops under intercrop or in rotation. There is currently insufficient information on the diversity of indigenous rhizobial populations in the soils of Lake Victoria basin in western Kenya which associate with bambara groundnuts. In this study, one local bambara groundnut accession was used to trap root nodule bacteria from four soils obtained from farmers' fields in Lake Victoria basin, western Kenya. Sixty four rhizobial isolates were obtained from the soils and morphologically characterized on Yeast Mannitol Extract Agar (YEMA) with Congo red and Bromothymol blue (BTB). Molecular evaluation was done using 16S rRNA genes to distinguish between the isolates. Results of morphological characterization showed majority (70\%) of the isolates had very fast and fast growth rates on YEMA, 26\% were intermediate while 3\% were slow growers. The fast, very fast and some intermediates $(70 \%)$ showed positive acid reaction while the rest showed positive reaction in alkaline conditions on YEMA with BTB. The 16S rRNA gene sequences had greater than $97 \%$ similarity to diverse genera including Rhizobium sp., Bradyrhizobium sp., Burkholderia sp. and Agrobacterium sp. previously isolated from crop plants. Phylogenetic analysis of eighteen representative sequences showed the presence of three clades with Rhizobium and Agrobacterium type sequences occurring in a single clade while Bradyrhizobiumand Burkholderia type sequences clustered into separate clades. In glasshouse experiments, seven isolates identified as Bradyrhizobium sp. and Burkholderia sp. and one Rhizobium sp. produced significantly $(\mathrm{P} \leq 0.05)$ higher nodule number per plant which were all effective with correspondingly high total biomass values of above $1.1 \mathrm{~g}$ per plant. The rest of the isolates showed significantly $(\mathrm{P} \leq 0.05)$ low levels of nodulation most of which were ineffective and resulted in significantly $(\mathrm{P} \leq 0.05)$ less plant dry matter. Isolates BAMKis12, BAMKis8, BAMKis4, BAMKbay8 and BAMsp3 genetically characterized as Bradyrhizobium sp. and Burkholderia sp. respectively can potentially be used as biofertilizers in inoculation programmes to improve the productivity of bambara groundnuts in the region.
\end{abstract}

\section{INTRODUCTION}

Symbiotic nitrogen fixation between leguminous plants and the $\alpha$ - and $\beta$-proteobacteria bacteria, collectively known as the 'rhizobia', results in reduction of free atmospheric nitrogen into ammonia that can fully or partially satisfy the nitrogen demand of the host plant [1-4]. This process is a sustainable and low-cost alternative to inorganic fertilizers in African small farming systems, although it is highly underutilized partly

* Corresponding Author

Department of Biological Sciences, Chuka University, P. O. Box 109-40600, Chuka, Kenya. Email : benboyih@gmail.com , Tel +254-724694613 because of insufficient information on its mechanism, biological background and management.

An important strategy for overcoming this drawback is the identification of resident (both native and naturalized) and environmentally adaptable rhizobial strains with superior symbiotic abilities and their utilization in local cropping systems [5].Through methodical isolation and screening for symbiotic effectiveness, it is possible to identify elite resident strains with adaptive abilities for higher nodulation, increased plant nitrogen content and improved crop productivity.

Bambara groundnut (Vigna subterranea L. Verdc) is the second most important African indigenous grain legume after 
cowpea [6] and it belongs to the family Leguminosae, subfamily Papilionoideae and 'tribe' Phaseoleae [7]. In Lake Victoria basin of Western Kenya, bambara groundnuts has gained prominence as an alternative dietary protein source with numerous agronomic advantages to smallholder farmers. It is drought tolerant [6] and is grown in mixed intercropping systems with no addition of fertilizers because of its ability to form symbiosis with root nodule bacteria fixing nitrogen into the soil [8]. However, information on nitrogen-fixing bacteria symbiotic to bambara groundnuts in the soils of this region is largely unexplored yet it has great potential in soil fertility management and resultant increased crop yields. Given the variation in physicochemical properties of the soils of Lake Victoria basin [9], selection of competent rhizobia for bambara groundnuts in the different soils is a necessary step towards improving its production.

Studies on bambara groundnut symbioses in other parts of the world have indicated it is non-selective in its rhizobial requirements [10] although it shows increased yield and symbiotic efficiency under inoculation with Bradyrhizobium sp. [11]. Sprent and colleagues [7] listed five $\alpha$-proteobacteria members, including Rhizobium, Bradyrhizobium, Azorhizobium, Ensifer and Mesorhizobium, as possible nodulators of bambara groundnuts although their levels of effectiveness is not fully established [12]. More recently, [13] reported the highly 'promiscuous' nature of bambara groundnuts forming nitrogen-fixing symbiosis with a wide range of bacteria, including some members of the $\beta$ proteobacteria such as the N-fixing Burkholderia. Despite these advances, it still remains to be determined if the diverse groups symbiotic to bambara groundnuts exist in the soils of Lake Victoria basin in Kenya, and more crucially if they have agronomic advantages to smallholder farming systems.

Edaphic factors and prevailing environmental conditions have previously been shown to determine the distribution of resident rhizobial populations. For instance, soil $\mathrm{pH}$ and $\mathrm{P}$ [14]; [15]; [16]; [5], temperature [17] salinity and moisture content [18] have a strong influence on the diversity of rhizobial strains within diverse agro-ecological regions. Resident rhizobia develop ecological strategies to survive the prevailing conditions and comparative tests against commercial strains might reveal strains with better influence on $\mathrm{N}$-fixation and plant growth promotion. Sixty four rhizobial strains symbiotic to bambara groundnuts in soils of Lake Victoria basin were isolated and we combined morphological and molecular identification using 16S rRNA gene sequences to determine their diversity. The symbiotic status of eighteen representative strains was determined against one reference strain Bradyrhizobium sp. strain KFR269 and one commercial strain Bradyrhizobium japonicum strain USDA110.

\section{MATERIALS AND METHODS}

\subsection{Soil sampling procedures}

Soil sampling was done at selected farmers' fields, which had no history of inoculation, in Kisumu, Port Victoria, Kendu Bay and Karungu within the Lake Victoria basin. Site characteristics are listed in Table 1. At each sampling point, $1 \mathrm{~kg}$ of soil was collected from a depth of $5-20 \mathrm{~cm}$ using a shovel. The shovel was cleaned between sampling with 5\% sodium hypochlorite solution, then rinsed with water three times and dried using a sterile cloth. Within each site, four replicate samples were collected within an area of $10 \mathrm{~m}^{2}$ by randomly sampling four corners. The soil samples were then mixed to form a composite sample. The soil samples were placed in brown paper bags and stored away from sunlight at room temperature and subsequently used for soil analysis and rhizobia isolation.

Table 1. Characteristics of soil sampling sites and identities of isolates obtained per site.

\begin{tabular}{|c|c|c|c|c|c|c|}
\hline Site & $\begin{array}{l}\text { Site } \\
\text { location }\end{array}$ & $\begin{array}{l}\text { Agro- } \\
\text { climatic } \\
\text { zone }\end{array}$ & $\begin{array}{l}\text { Soil } \\
\text { type }\end{array}$ & $\begin{array}{l}\text { Legume } \\
\text { history }\end{array}$ & $\begin{array}{l}\text { No. of } \\
\text { isolates }\end{array}$ & $\begin{array}{l}\text { Isolate } \\
\text { identities }\end{array}$ \\
\hline Kisumu & $\begin{array}{l}0^{0} 6^{\prime} 0 \mathrm{~N} \\
34^{0} 45^{\prime} 0 \mathrm{E}\end{array}$ & $\begin{array}{l}\text { Sub- } \\
\text { humid } \\
\text { lower } \\
\text { midland }\end{array}$ & $\begin{array}{l}\text { Clay } \\
\text { loam }\end{array}$ & $\begin{array}{l}\text { Common } \\
\text { beans }\end{array}$ & 22 & BAMKis1- 22 \\
\hline Karungu & $\begin{array}{l}0^{0} 51^{\prime} 0 \mathrm{~S} \\
34^{0} 8^{\prime} \\
60 \mathrm{E}\end{array}$ & $\begin{array}{l}\text { Semi- } \\
\text { humid } \\
\text { lower } \\
\text { midland }\end{array}$ & $\begin{array}{l}\text { Sandy } \\
\text { loam }\end{array}$ & $\begin{array}{l}\text { Common } \\
\text { beans }\end{array}$ & 16 & BAMKar1- 16 \\
\hline $\begin{array}{l}\text { Kendu } \\
\text { bay }\end{array}$ & $\begin{array}{l}0^{0} 22^{\prime} 0 \mathrm{~S} \\
34^{0} 38^{\prime} \\
60 \mathrm{E}\end{array}$ & $\begin{array}{l}\text { Semi- } \\
\text { humid } \\
\text { lower } \\
\text { midland }\end{array}$ & Sand & Groundnut & 14 & $\begin{array}{l}\text { BAMKbay1 - } \\
14\end{array}$ \\
\hline $\begin{array}{l}\text { P. } \\
\text { Victoria }\end{array}$ & $\begin{array}{l}0^{0} 6^{\prime} 0 \mathrm{~N} \\
33^{0} 58^{\prime} \\
0 \mathrm{E}\end{array}$ & $\begin{array}{l}\text { Sub- } \\
\text { humid } \\
\text { lower } \\
\text { midland }\end{array}$ & $\begin{array}{l}\text { Sandy } \\
\text { loam }\end{array}$ & $\begin{array}{l}\text { Common } \\
\text { beans }\end{array}$ & 12 & BAMsp1-12 \\
\hline
\end{tabular}

\subsection{Soil analysis}

Soil samples were air dried, crushed using a wooden roller and passed through a $0.5 \mathrm{~cm}$ mesh to remove any plant or grass fragment. Four hundred grams of the prepared soil samples were placed in brown paper bags, tightly sealed and submitted to Kenya Agricultural Research Institute's National Agricultural Research Laboratories in Nairobi for soil chemical analysis. Soil pH was evaluated using a Pye-Unican $\mathrm{pH}$ meter Model 290-MK2, (Mettler-Toledo Inc, Canada) at a soil to water ratio of 1:2.5. A modified Walkley-Black dry combustion method was used to determine the percentage of organic $\mathrm{C}$ in the soil samples [19]. Total $\mathrm{N}$ was evaluated using the macro-Kjedahl method as modified by [19], while available $\mathrm{P}$ was analyzed by the Bauschand Lomb supertonic spectrophotometer after extraction using the BrayP1 method [20]. Exchangeable $\mathrm{K}$ and $\mathrm{Na}$ were evaluated using flame photometry while $\mathrm{Mn}, \mathrm{Cu}, \mathrm{Zn}$ and $\mathrm{Mg}$ were determined by titration using $0.02 \mathrm{~N}$ EDTA solution [21].

\subsection{Soil trapping, isolation and morphological characterization}

The host plant infection technique according to [22] was used to trap indigenous root nodule bacteria symbiotic to bambara groundnuts from the collected soil samples. A local landrace of bambara groundnut with cream colored seeds, preferred by farmers in the region because of early maturity, superior cooking quality and taste, was chosen for this study. The seeds were surface sterilized in $95 \%$ ethanol for $1 \mathrm{~min}$, followed by $2 \%$ sodium hypochlorite solution for 30 seconds and finally rinsed in five exchanges of sterile water. Plastic pots $(20 \mathrm{~cm}$ diameter and $25 \mathrm{~cm}$ 
height) were filled with soil samples and watered with sterile water until adequately wet. Five seeds were planted in each pot allowing adequate space for germination but were later thinned to two. Watering was done twice a day in the morning and evening. After 45 days of growth, plants were carefully uprooted and soil washed off the roots without detaching the nodules. Three to five wellformed nodules were sampled per pot and categorized depending on the size (small or large) for isolation. Nodules were surface sterilized by immersion in $96 \%$ ethanol for 3 seconds followed by immersion in $2 \%$ sodium hypochlorite for 3 minutes and finally rinsed several times in sterile water. They were crushed in three drops of sterile water using a sterile glass rod and streaked on Yeast Extract Mannitol Agar (YEMA) media with 10\% Congo red (CR) and repeated on YEMA with0.5\% Bromothymol blue (BTB). The plates were sealed and incubated in dark cabinets at $28{ }^{\circ} \mathrm{C}$ and observed daily for isolated colonies. Repeated streaking of single colonies on fresh YEMA plates resulted in sixty four isolates which were allocated identities as per the site of origin; the distribution is shown in Table 1. Morphological characterization was done to determine their growth rate, colony shape, colony appearance, colony texture and reaction in media $\mathrm{pH}$, according to the methods of [23].

\subsection{Evaluation of isolates using the 16S rRNA gene}

Sixty four pure isolates were genetically characterized using a 16S rRNA gene approach. Genomic DNA was extracted from pure bacterial isolates using the ZR Bacterial DNA MiniPrep $^{\mathrm{TM}}$ kit according to the manufacturer's specifications (Zymo Research Corp, South Africa). The concentration and purity of DNA was estimated using a Nanodrop ${ }^{\mathrm{TM}}$ Lite Spectrophotometer (Thermo Scientific Inc, USA) at 260-280 nm and by horizontal gel electrophoresis (Thistle Scientific Ltd, USA) on a $0.8 \%(\mathrm{w} / \mathrm{v})$ agarose gel at $100 \mathrm{~V}$ for $30 \mathrm{~min}$ and visualized under UV after staining with GelRed ${ }^{\mathrm{TM}}$ (Thermo Scientific, USA). The PCR primers targeting the bacterial 16S rRNA gene used were: 27F (AGA GTT TGA TCM TGG CTC AG) and 1492R (GGT TAC CTT GTT ACG ACGACT T) [24]; [25]. Bioneer AccuPower ${ }^{\circledR}$ PCR Premix (Bioneer Inc, USA) was used to perform PCR. To each $20 \mu \mathrm{l}$ Bioneer tube $\mu \mathrm{l}$ of $50 \mathrm{ng}$ template DNA, $0.5 \mu \mathrm{l}$ of 10 picomole of each primer and $18 \mu \mathrm{l}$ of nuclease free water were added and mixed. Amplification of $16 \mathrm{~S}$ rRNA gene region was performed in a programmable Mastercycler thermocycler (C1000-BioRad, USA) with an initial denaturing step at $94^{\circ} \mathrm{C}$ for 5 min, 30 cycles of denaturing at $94^{\circ} \mathrm{C}$ for $30 \mathrm{sec}$, primer annealing at $58^{\circ} \mathrm{C}$ for $1 \mathrm{~min}$, and primer extension at $72^{\circ} \mathrm{C}$ for $1 \mathrm{~min}$, followed by a final extension step at $72^{\circ} \mathrm{C}$ for $7 \mathrm{~min}$. PCR products were separated by horizontal gel electrophoresis on $1.5 \%(\mathrm{w} / \mathrm{v})$ agarose gel at $100 \mathrm{~V}$ for 45 mins and visualized under UV after staining with $2 \mu$ GelRed $^{\mathrm{TM}}$ (Thermo Scientific, USA). PCR products were purified using a Qiagen MinElute PCR Purification Kit (Qiagen Inc, USA) according to the manufacturer's protocol. Purified PCR products were sequenced at the Segolip Sequencing Unit, BecA-ILRIHub, by capillary sequencing on a $3730 x l$ DNA Analyzer, (Thermo Fisher Scientific Inc, USA). Forward and reverse sequences were assembled on CLC Main Workbench (CLC Bio, Version 6.8.3).

Assembled sequences were transferred to MEGA Version 6.0 software and aligned using CLUSTAL W according to [27]. Sequences were submitted to the NCBI BLAST portal (www.ncbi.blast.lnm.nih.gov) for a sequence similarity search, and sequences with greater than $97 \%$ similarity were retrieved for phylogenetic analysis. Evolutionary histories were inferred using the Neighbor-Joining method and distances computed using the Maximum Composite Likelihood [27]. Bootstrap tests (1000 replicates) were used to cluster associated taxa and replicate trees with above $50 \%$ likelihoods indicated on the branches. All trees were drawn to scale, with branch lengths in the same units as those of the evolutionary distances used to infer the phylogenetic tree. All positions containing gaps and missing data were eliminated.

\subsection{Determination of symbiotic status}

Sixty four root nodule bacteria colonies isolated from bambara groundnuts were evaluated by $16 \mathrm{~S}$ rRNA gene sequences and the maximum identity with those at the NCBI gene bank obtained. Based on the results, 18 isolates representative of all the genera identified were selected for determination of symbiotic status. One strain (Bradyrhizobium sp. KFR 269) from Dr. David Odee's rhizobial collection at Kenya Forestry Research Institute's headquarters in Muguga and a commercial strain Bradyrhizobium japonicum USDA110 were chosen as reference strains based on previous reports that bambara groundnuts nodulate better with Bradyrhizobium sp. [7].

Bambara groundnut seeds were prepared as previously described and spread on water-agar (ratio 4:1) plates. The seeds were inverted and incubated in dark at $25^{\circ} \mathrm{C}$ for germination and were considered to be successfully germinated when their radicles reached the same length as the seed or longer. Improvised Leonard jars were prepared by sterilizing in 5\% sodium hypochlorite solution for 15 minutes. Vermiculite obtained from a commercial supplier in Nairobi's industrial area was sterilized at $121^{\circ} \mathrm{C}$ for 1 hour and the $\mathrm{pH}$ normalized to near neutral using $5 \% \mathrm{CaCO}_{3}$ solution and then filled in the jars. Two seedlings were aseptically transferred into the vermiculite and watered using sterile $\mathrm{N}$-free nutrient solution [28] and covered with clean brown paper bags to minimize evaporation while the seedlings became established. The inoculum was prepared by streaking each isolate on freshly prepared YEMA plates. One $\mathrm{ml}$ of the pure culture was aseptically picked, re-suspended into sterile bottles containing $10 \mathrm{ml}$ of YEMA broth and left on a shaker overnight. Eight replicates per isolate were inoculated directly around seedling hypocotyls three days after establishment using sterile disposable pipette tips. On each occasion, $1 \mathrm{ml}$ (about $10^{8}$ cells) of bacterial suspension was used to inoculate each seedling. Immediately after inoculation, vermiculite surfaces were covered with steam sterilized sand to inhibit contamination. Glasshouse controlled conditions were a $16 / 8 \mathrm{~h}$ light/dark cycle, $25 / 18^{\circ} \mathrm{C}$ day/night temperature and $70 \%$ relative humidity. Test seedlings and the negative control were irrigated twice per week with a nitrogen-free nutrient solution 
Table 2.Chemical characteristics of soils collected from four sites within Lake Victoria basin.

\begin{tabular}{|c|c|c|c|c|c|c|c|c|c|c|c|c|}
\hline Site & pH & $\mathbf{N}(\%)$ & Org. C (\%) & $\begin{array}{c}\mathbf{P} \\
(\mathbf{p p m})\end{array}$ & $\begin{array}{c}\mathbf{K} \\
(\mathbf{m} . \mathrm{e} \%)\end{array}$ & $\begin{array}{c}\text { Ca } \\
(\mathbf{m . e} \%)\end{array}$ & $\begin{array}{c}\mathrm{Mg} \\
(\mathbf{m . e \%})\end{array}$ & $\begin{array}{c}\text { Mn } \\
(\mathbf{m . e \%})\end{array}$ & $\begin{array}{c}\mathrm{Cu} \\
(\mathbf{p p m})\end{array}$ & $\begin{array}{c}\mathbf{F e} \\
(\mathbf{p p m})\end{array}$ & $\begin{array}{c}\mathbf{Z n} \\
(\mathbf{p p m})\end{array}$ & $\begin{array}{c}\mathrm{Na} \\
(\mathrm{m} . \mathrm{e} \%)\end{array}$ \\
\hline Kendu Bay & 6.26 & 0.17 & 1.66 & 23.00 & 0.62 & 3.50 & 7.60 & 0.84 & 1.19 & 14.50 & 6.23 & 0.26 \\
\hline P. Victoria & 6.30 & 0.15 & 1.51 & 19.50 & 0.56 & 3.95 & 7.85 & 0.61 & 1.04 & 15.98 & 8.46 & 0.25 \\
\hline Kisumu & 4.10 & 0.15 & 1.44 & 10.00 & 0.20 & 2.48 & 2.52 & 0.59 & 1.09 & 14.80 & 8.91 & 0.07 \\
\hline Karungu & 4.11 & 0.14 & 1.29 & 5.00 & 0.19 & 1.37 & 2.76 & 0.67 & 1.06 & 18.07 & 6.00 & 0.07 \\
\hline
\end{tabular}

while the positive control was inoculated with $0.05 \% \mathrm{KNO}_{3}$ solution to supply the plants with nitrogen.

After 5 weeks, the growth media was gently shaken off, the roots carefully washed and the number of well-formed nodules counted. Nodules, roots and shoot from the same pot were considered to belong to the same unit and were put in marked $2 \times 1.75 \mathrm{~cm}$ zip lock polythene bags for laboratory analysis. Fresh weights in grams of each unit was taken in four replicates and recorded. Dry weights of nodules, shoots and roots were obtained by putting the samples in an oven set at $70^{\circ} \mathrm{C}$ for four days followed by weighing on an analytical electronic balance (The Lab Depot Inc, USA). The data collected were subjected to analysis of variance using Genstat $16^{\text {th }}$ Edition (www.genstat.co.uk) and where significant, means were separated using Least Significant Difference at $\mathrm{p} \leq 0.05$.

\section{RESULTS}

\subsection{Chemical analysis of soils}

Soils chemical properties of the four study sites are given in Table 2. Soil samples from Kendu Bay and Port Victoria were moderately acidic with $\mathrm{pH}$ value ranges of $6.26-6.30$ unlike Karungu and Kisumu which had strongly acidic soils at 4.10-4.11. Soil P levels varied with soils from Kendu Bay and Port Victoria having high values ranging between $19.5-23.00 \mathrm{ppm}$ while soils from Kisumu and Karungu had quite low values ranging from 5 to $10 \mathrm{ppm}$. Other soil chemical factors varied as follows: $\mathrm{Mg}$ (7.60 $7.85 \mathrm{me} \%$ for Kendu Bay and Port Victoria and $2.52-2.76$ m.e\% for Kisumu and Karungu); K (0.19-0.20 m.e \% for Kisumu and Karungu and $0.56-0.62 \mathrm{me} \%$ for Kendu bay and Port Victoria); $\mathrm{Ca}(3.50$ - 3.95 m.e\% for Kendu Bay and Port Victoria and 1.37 2.48 m.e $\%$ for Kisumu and Karungu) Na; $0.26-0.25$ m.e\% for Kendu Bay and Karungu and 0.07 m.e\% for Kisumu and Karungu).

\subsection{Morphology of isolates}

Morphological differences and distribution of 64 isolates based on the site of origin are listed on Table 3. Seventy percent were classified as fast and very fast growers, $26 \%$ intermediate and3\% were slow growers. Most of slow and intermediate growing isolates were from Kisumu soils (23\%) while the fast and very fast ones were evenly distributed in the other study sites. Reaction on YEMA with BTB distinguished $67.19 \%$ acid producers most of which were isolated from Kendu Bay and Karungu soils and majority had watery or milky translucent coloration. In a few cases, there was no clear distinction of $\mathrm{pH}$ reaction as depicted by a remotely yellow-green color of the medium, but these were however grouped with acid producers due to occurrence of the yellow color. Only eight isolates $(12.5 \%)$ were dense and elastic in appearance, four of which were native to Kisumu soils while $87.5 \%$ were diffuse and non-elastic out of which $14,18,11$ and 13 were from Kendu Bay, Kisumu, Port Victoria and Karungu soils respectively. Colony shape separated $84 \%$ dome shaped colonies with entire margins out of which 20 originated from Kisumu soils while the rest, either flat and entire (14\%) or conical and glabrous (one isolate) colonies originating from the other sites.

Table 3. Morphological features and distribution of sixty four root nodule bacteria colonies isolated from bambara groundnut in four soils of Lake Victoria basin.

\begin{tabular}{|c|c|c|c|}
\hline Characteristics & $\begin{array}{l}\text { No. of } \\
\text { isolates }\end{array}$ & $\begin{array}{l}\% \\
\text { isolates }\end{array}$ & $\begin{array}{l}\text { Distribution based on sites of } \\
\text { origin }\end{array}$ \\
\hline \multicolumn{4}{|c|}{ Growth Rate(days) } \\
\hline$\leq 2$ (Very fast) & 4 & 4.67 & $\operatorname{Kbay}(1), \operatorname{Kis}(2), S p(0), \operatorname{Kar}(1)$ \\
\hline 3 to 5 (Fast) & 34 & 65.61 & Kbay (11), Kis (5), Sp(7), Kar (11) \\
\hline $\begin{array}{l}6 \text { to } 7 \\
\text { (Intermediate) }\end{array}$ & 15 & 26.65 & Kbay (2), Kis (9), Sp(3), Kar (1) \\
\hline 8 to 15 (Slow) & 11 & 3.12 & Kbay (0), Kis (6), Sp(2), Kar (3) \\
\hline \multicolumn{4}{|c|}{ Alkaline/Acid reaction } \\
\hline Alkaline & 21 & 32.81 & Kbay (2), Kis (14), Sp(2), Kar (3) \\
\hline Acid & 43 & 67.19 & $\operatorname{Kbay}(12), \operatorname{Kis}(8), \operatorname{Sp}(10), \operatorname{Kar}(13$ \\
\hline \multicolumn{4}{|l|}{ Color and Texture } \\
\hline $\begin{array}{l}\text { White and } \\
\text { opaque }\end{array}$ & 35 & 54.68 & Kbay (10), Kis (8), Sp(7), Kar (10) \\
\hline $\begin{array}{l}\text { Watery and } \\
\text { translucent }\end{array}$ & 16 & 25 & Kbay (3), Kis (8), Sp(2), Kar (3) \\
\hline $\begin{array}{l}\text { Milky and } \\
\text { translucent }\end{array}$ & 13 & 20.31 & Kbay (1), Kis (6), $\mathrm{Sp}(3), \operatorname{Kar}(3)$ \\
\hline \multicolumn{4}{|l|}{ Appearance } \\
\hline $\begin{array}{l}\text { Dense and } \\
\text { elastic }\end{array}$ & 8 & 12.5 & Kbay (0), Kis (4), Sp(1), Kar (3) \\
\hline $\begin{array}{l}\text { Diffuse and non } \\
\text { elastic }\end{array}$ & 56 & 87.5 & $\begin{array}{l}\text { Kbay (14), Kis (18), Sp(11), Kar } \\
\text { (13) }\end{array}$ \\
\hline \multicolumn{4}{|l|}{ Shape } \\
\hline $\begin{array}{l}\text { Dome with } \\
\text { entire margin }\end{array}$ & 54 & 84.37 & $\begin{array}{l}\text { Kbay (14), Kis (20), Sp(9), Kar } \\
\text { (11) }\end{array}$ \\
\hline $\begin{array}{l}\text { Flat with entire } \\
\text { margins }\end{array}$ & 9 & 14.06 & Kbay (0), Kis (2), Sp(2), Kar (5) \\
\hline $\begin{array}{l}\text { Conical round } \\
\text { margins }\end{array}$ & 1 & 1.56 & Kbay (0), Kis (0), Sp(1), Kar (0) \\
\hline
\end{tabular}

KEY:Kbay - Kendu Bay, Kis - Kisumu, Sp - Port Victoria and Kar - Karungu isolates. The number of isolates per site are in parenthesis

\subsection{S rRNA gene analysis}

BLAST analysis of the 16S rRNA gene sequences resulted in $97 \%$ and above similarity indices with four rhizobia genera including Bradyrhizobium sp., Rhizobium sp., Burkholderia sp. and Agrobacterium sp. Eighteen representative sequences from 


Kendu bayisolates
- Port Victoriaisolates
Karungu isolates
Kisumu isolates

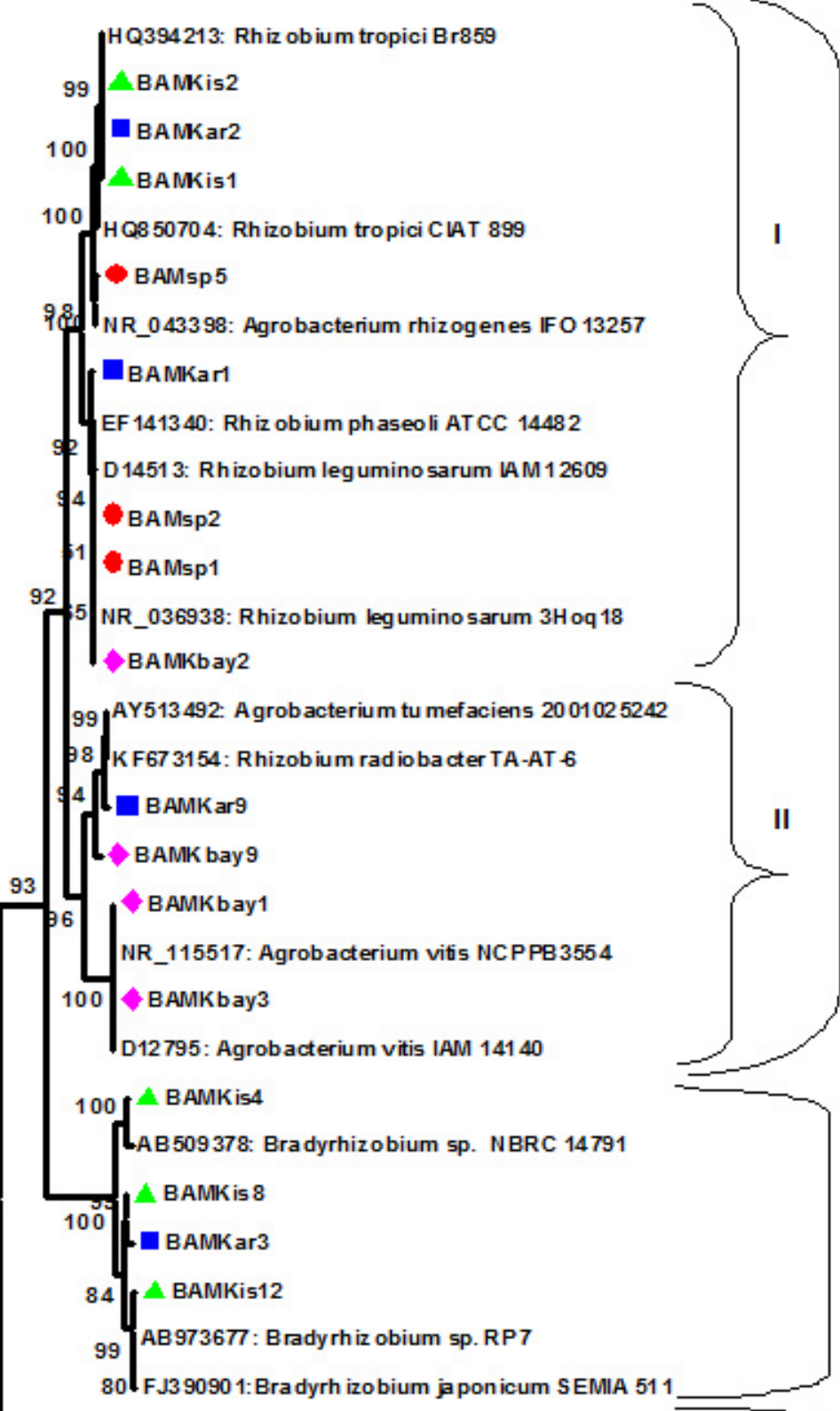

A
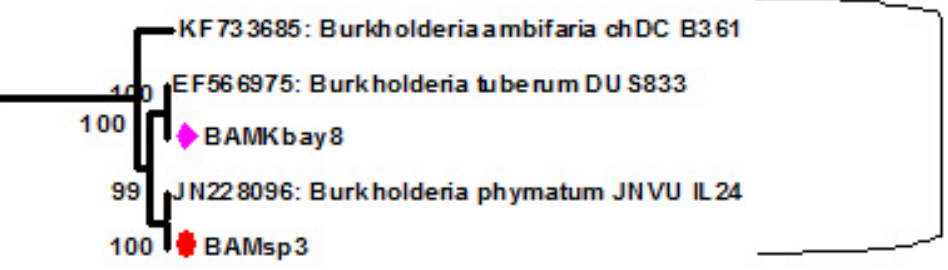

KJ944 112: Bacillus sp. L106

0.1

Fig 1. A Neighbor joining phylogenetic tree built using eighteen 16S rRNA gene sequences obtained from root nodule bacteria isolated from bambara groundnuts in four soils of Lake Victoria basin. Bacillus sp. strain L106 (KJ944112) was used as an out-group to root the tree. 
this study and sequences with the greatest homologues from NCBI genebank used in phylogenetic analysis are listed in Table 4. The phylogenetic tree constructed divided the isolates into three groups as shown in Fig 1. Group A had Rhizobium and Agrobacterium that diversified into two separate sub-clades at $100 \%$ bootstrap support.

Table 4. Identities of eighteen rhizobial isolates based on 16S rRNA gene sequences and accession numbers and origins of sequences with highest similarity values.

\begin{tabular}{|c|c|c|c|c|c|}
\hline $\begin{array}{l}\text { Isolate } \\
\text { Identity }\end{array}$ & Acc. No. & $\begin{array}{l}\text { 16S rRNA gene } \\
\text { identification }\end{array}$ & $\begin{array}{l}\% \\
\text { Identity }\end{array}$ & $\begin{array}{l}\text { NCBI } \\
\text { sequences } \\
\text { with } \\
\text { greatest } \\
\text { similarity }\end{array}$ & $\begin{array}{l}\text { Country } \\
\text { of origin }\end{array}$ \\
\hline BAMKar1. & KJ668869 & Rhizobium sp. & $99 \%$ & NR_044112 & Peru \\
\hline BAMKar2. & KJ668862 & Rhizobium sp. & $100 \%$ & HQ394213 & Spain \\
\hline BAMKar3 & KF879077 & Bradyrhizobium sp. & $99 \%$ & AB973677 & Thailand \\
\hline BAMKar9 & KM362440 & Agrobacterium sp. & $97 \%$ & KF673154 & China \\
\hline BAMKbay1 & KM362437 & Agrobacterium sp. & $100 \%$ & NR_115517 & Japan \\
\hline BAMKbay2. & KJ668864 & Rhizobium sp. & $99 \%$ & JQ0855251.1 & Mexico \\
\hline BAMKbay3 & KM362430 & Agrobacterium sp. & $100 \%$ & D12795 & Japan \\
\hline BAMKbay8 & KM362442 & Burkholderia sp. & $99 \%$ & EF566975 & $\begin{array}{l}\text { South } \\
\text { Africa }\end{array}$ \\
\hline BAMKbay9 & KM362441 & Agrobacterium sp. & $99 \%$ & AY513492 & USA \\
\hline BAMKis1. & KJ736763 & Rhizobium sp. & $100 \%$ & HQ850704 & Spain \\
\hline BAMKis12 & KF879076 & Bradyrhizobium sp. & $100 \%$ & FJ390916 & USA \\
\hline BAMKis2. & KJ668867 & Rhizobium sp. & $97 \%$ & KF787792 & China \\
\hline BAMKis4 & KF879078 & Bradyrhizobium sp. & $97 \%$ & HQ704815 & Peru \\
\hline BAMKis8 & KF879074 & Bradyrhizobium sp. & $97 \%$ & AB973677 & Thailand \\
\hline BAMsp1. & KJ668865 & Rhizobium sp. & $100 \%$ & N_R036938 & Mexico \\
\hline BAMsp2. & KJ668866 & Rhizobium sp. & $99 \%$ & D14513 & Japan \\
\hline BAMsp3 & KM362438 & Burkholderia sp. & $97 \%$ & JN228096 & India \\
\hline BAMsp6 & KM362439 & Agrobacterium sp. & $100 \%$ & NR_043398 & Japan \\
\hline
\end{tabular}

In sub-clade AI were isolates BAMsp1 and BAMsp2 from Port Victoria, BAMKbay2 from Kendu bay and BAMKar1 from Karungu which clustered with Rhizobium leguminosarum strains 3Hoq18 and IAM12690 and Rhizobium phaseoli strain ATTC14482 at 97\% support. Four isolates (BAMKis1, BAMKis2, BAMKar2 and BAMsp5) separated from the first group at 100\% bootstrap to cluster with Rhizobium tropici strain CIAT899, Rhizobium tropici strain Br859 and Agrobacterium rhizogenes strain IFO13257. Sub-clade AII constituted three isolates from Kendu bay (BAMKbay1, BAMKbay3 and BAMKbay9) which clustered at $100 \%$ bootstrap support with Agrobacterium vitis strain NCPB3554 and $A$. vitis strain IAM14140. In the same clade was one BAMKar5 from Karungu which was closely related to Agrobacterium tumefaciens strain 2001025242 and Rhizobium radiobacter strain TA-AT-6 (formerly A. tumefaciens). Three isolates from Kisumu soils and one from Karungu were grouped together in clade B with Bradyrhizobium sp. strain NBRC14791, Bradyrhizobium sp. strain RP7 and B. japonicum strain SEMIA 511 at $100 \%$ bootstrap support. Group C had two isolates BAMsp3 and BAMKbay6 clustering in the same group as Burkholderia tuberum strain STM4287 and Burkholderia phymatum strain JNVU IC14.

\subsection{Symbiotic characterization of isolates}

Inoculation of Bambara groundnuts with eighteen isolates and two reference strains resulted in variation in nodule, shoot and root factors evaluated as shown in Table 5.

Table 5. Symbiotic status of eighteen bambara groundnut rhizobial isolates in comparison with two reference strains.

\begin{tabular}{|c|c|c|c|c|c|c|c|c|c|c|c|}
\hline Isolate & Growth rate & 16S rRNA gene identity & EFF & NNO & NIC & LCL & $\begin{array}{l}\text { NFW } \\
(\mathrm{g})\end{array}$ & NDW (g) & $\begin{array}{l}\text { SDW } \\
(\mathrm{g})\end{array}$ & $\begin{array}{l}\text { RDW } \\
\text { (g) }\end{array}$ & $\begin{array}{l}\text { TBM } \\
(\mathrm{g})\end{array}$ \\
\hline$+\mathrm{N}$ & & & $\mathrm{C}$ & 0.0 & 0 & 2.00 & 0.000 & 0.000 & 2.121 & 0.132 & 2.253 \\
\hline$-\mathrm{N}$ & & & $\mathrm{C}$ & 0.0 & 0 & 1.00 & 0.000 & 0.000 & 0.991 & 0.200 & 1.191 \\
\hline KFR 259 & Slow & Bradyrhizobium sp. & $\mathrm{R}$ & 34.8 & 3 & 3.00 & 0.286 & 0.044 & 0.661 & 0.186 & 0.891 \\
\hline USDA 110 & Slow & Bradyrhizobium sp. & $\mathrm{R}$ & 21.2 & 3 & 3.00 & 0.314 & 0.040 & 0.842 & 0.259 & 1.141 \\
\hline BAMKis12 & Slow & Bradyrhizobium sp. & $\mathrm{HE}$ & 49.0 & 3 & 3.00 & 0.387 & 0.064 & 1.005 & 0.168 & 1.237 \\
\hline BAMKis8 & Slow & Bradyrhizobium sp. & $\mathrm{HE}$ & 43.0 & 3 & 3.00 & 0.321 & 0.061 & 0.933 & 0.159 & 1.153 \\
\hline BAMKis4 & Slow & Bradyrhizobium sp. & $\mathrm{HE}$ & 35.8 & 3 & 3.00 & 0.316 & 0.056 & 0.907 & 0.154 & 1.117 \\
\hline BAMKbay8 & Fast & Burkholderia sp. & $\mathrm{HE}$ & 34.2 & 3 & 3.00 & 0.293 & 0.040 & 0.896 & 0.149 & 1.085 \\
\hline BAMsp3 & Fast & Burkholderia sp. & $\mathrm{HE}$ & 37.2 & 3 & 3.00 & 0.306 & 0.053 & 0.795 & 0.186 & 1.034 \\
\hline BAMKis1. & Fast & Rhizobium sp. & $\mathrm{HE}$ & 25.8 & 3 & 3.00 & 0.328 & 0.059 & 1.296 & 0.299 & 1.654 \\
\hline BAMKar3 & Slow & Bradyrhizobium sp. & $\mathrm{HE}$ & 22.0 & 3 & 3.00 & 0.173 & 0.026 & 0.759 & 0.208 & 0.993 \\
\hline BAMKar2. & Fast & Rhizobium sp. & $\mathrm{E}$ & 15.5 & 2 & 3.00 & 0.288 & 0.037 & 0.767 & 0.210 & 1.014 \\
\hline BAMKar1. & Fast & Rhizobium sp. & $\mathrm{E}$ & 13.3 & 2 & 3.00 & 0.223 & 0.068 & 0.994 & 0.513 & 1.575 \\
\hline BAMKis2. & Fast & Rhizobium sp. & $\mathrm{E}$ & 12.6 & 2 & 3.00 & 0.217 & 0.013 & 0.665 & 0.477 & 1.155 \\
\hline BAMKbay1 & Intermediate & Agrobacterium sp. & $\mathrm{E}$ & 11.3 & 2 & 3.00 & 0.197 & 0.029 & 0.873 & 0.386 & 1.288 \\
\hline BAMsp2. & Fast & Rhizobium sp. & $\mathrm{E}$ & 10.9 & 2 & 3.00 & 0.148 & 0.026 & 0.754 & 0.379 & 1.159 \\
\hline BAMsp1. & Fast & Rhizobium sp. & $\mathrm{E}$ & 10.1 & 2 & 3.00 & 0.098 & 0.023 & 0.661 & 0.346 & 1.030 \\
\hline BAMKbay2. & Fast & Rhizobium sp. & $\mathrm{I}$ & 1.5 & 1 & 1.00 & 0.027 & 0.030 & 0.615 & 0.337 & 0.982 \\
\hline BAMKar6 & Intermediate & Agrobacterium sp. & I & 1.3 & 1 & 1.00 & 0.011 & 0.019 & 0.581 & 0.185 & 0.785 \\
\hline BAMsp5 & Intermediate & Agrobacterium sp. & I & 1.8 & 1 & 1.00 & 0.017 & 0.020 & 0.695 & 0.191 & 0.906 \\
\hline BAMKbay 9 & Intermediate & Agrobacterium sp. & I & 0.0 & 0 & 1.00 & 0.000 & 0.000 & 0.519 & 0.258 & 0.777 \\
\hline BAMKbay3 & Intermediate & Agrobacterium sp. & I & 0.0 & 0 & 1.00 & 0.000 & 0.000 & 0.838 & 0.131 & 0.669 \\
\hline \multicolumn{4}{|c|}{ SE } & 2.571 & - & - & - & 0.113 & 0.265 & 0.793 & 0.354 \\
\hline \multicolumn{4}{|c|}{$\operatorname{LSD}_{(0.05)}$} & 06.25 & - & - & - & 0.449 & 0.134 & 0.177 & 0.605 \\
\hline \multicolumn{4}{|c|}{$\mathrm{CV}_{(\%)}$} & 16.6 & - & - & - & 38.8 & 31.0 & 32.9 & 31.4 \\
\hline
\end{tabular}

$+\mathrm{N}$ - Inorganic nitrogen control; -N - Non treated control; EFF - Effectiveness; NNO - Nodule number per plant; NIC - Nodule Internal Colour; NFW - Nodule

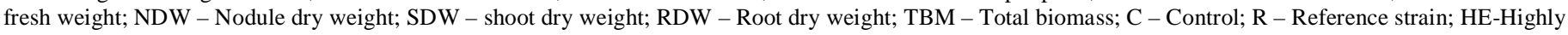
effective, E-Effective, I-Ineffective. 
Isolates genetically identified as Bradyrhizobium sp., Burkholderia sp. and one Rhizobium sp. produced highly effective nodules which numbered above 20 per plant; as was observed in the reference strains. Interestingly, the Bradyrhizobium isolates were obtained from Kisumu and Karungu soils while the latter two genera were evenly distributed in other sites. Partly effective nodules were mostly found in isolates genetically identified as Rhizobium sp. except one Agrobacterium sp., a group that otherwise produced ineffective nodules. Comparison of shoot dry weight showed that two of our isolates (BAMKis1 and BAMKis12) achieving statistically similar $(\mathrm{P} \leq 0.05)$ dry weights to the un-inoculated positive control while none was statistically identical $(\mathrm{P} \leq 0.05)$ to the un-inoculated negative control. Interestingly the two isolates were from the same site and were morphologically determined as slow growers. Root dry weight, total biomass and leaf color values were significantly higher in the isolates which gave high nodule number per plant and were mostly classified as Bradyrhizobium sp. or Burkholderia sp.

\section{DISCUSSION}

Bambara groundnut was used as a trap plant on soils from four sites within Lake Victoria basin in Kenya and resultant root nodule bacteria isolates characterized and evaluated for symbiotic status. The results showed high levels of diversity within the sixty four isolates both phenotypically and by 16S RNA gene identities. Edaphic factors of the site of isolation particularly soil $\mathrm{pH}$ and $\mathrm{P}$ levels influenced the relative dominance or absence of the different groups at any particular site. Thirty eight isolates had very fast or fast growing colonies on YEMA reaching a diameter of about $1 \mathrm{~mm}$ in less than five days out of which 22 were from the slightly acidic ( $\mathrm{pH} 6.26-6.30)$ and high $\mathrm{P}$ soils $(19.5-23.0 \mathrm{ppm})$ of Kendu bay and Port Victoria while the rest were from the extremely acidic ( $\mathrm{pH} 4.10$ - 4.11) and low P (5 - 10 ppm) soils of Kisumu and Karungu soils. Only $11 \%$ of all the isolates tested were slow growers and about $87 \%$ of these were obtained from Kisumu and Karungu soils. Fifteen neither fast nor slow growing isolates were classified as intermediates and were evenly distributed within the four sites indicating their lack of preference for specific soil features. However, reaction on BTB had most intermediate isolates producing a pale yellow color indicating their ability to react in acid environments.

Comparison of our 16S rRNA gene sequences with those deposited in the NCBI gene bank database showed that in its natural habitat, bambara groundnut forms symbiosis withroot nodule bacteria of different genera including Bradyrhizobium (BAMKis12, BAMKis8, BAMKis4 and BAMKar3), Burkholderia (BAMKbay8, BAMsp3), Rhizobium (BAMKis1, BAMKar1, BAMKar2, BAMKis2, BAMsp2, BAMsp1 and BAMKbay2) and Agrobacterium(BAMKbay1, BAMKar6, BAMsp5,BAMKbay9 and BAMKbay3). The wide diversity of micro-symbionts of bambara groundnuts established in this study concurs with a previous report by [7] showing it to be capable of free nodulation with different rhizobial groups making it a 'promiscuous' host. Symbiotic promiscuity has been shown to be beneficial when legumes associate effectively with different rhizobia species allowing their adaptation to different environments [29]; [30]; [31], although differences in the number of symbiotic partners and the level of their effectiveness has also been observed [32]. For instance, common beans (Phaseolus vulgaris) are promiscuous hosts nodulated by six species of Rhizobium, five species of Sinorhizobium, and several Bradyrhizobia [33] yet it has preference for some species depending on the site environmental characters. Similar findings of diverse nodulators of bambara groundnuts was observed in this study, which necessitated tests to determine their symbiotic preferences although differences in soil characteristics of the site of isolation could have played a role in the diversity.

Soil chemical factors, particularly soil $\mathrm{pH}$ and $\mathrm{P}$ levels seemed to affect the distribution of the isolates into different genera as they varied within the four study sites. For instance, all the slow growing Bradyrhizobia isolates were obtained from the extremely acidic and low P soils of Kisumu and Karungu demonstrating the tolerance of this group to these extreme conditions. When tested in inoculation trials, all the treatments with Bradyrhizobium sp. isolates produced highly effective nodules with intensely pink internal nodule colors. The treatments involving Bradyrhizobium sp. isolates also resulted in high total biomass values outperforming the commercial Bradyrhizobium japonicum strain USDA110 and the nitrogen control. On the other hand, we were unable to obtain Bradyrhizobia sp. isolates from the moderately acidic and high P soils of Kendu bay and Port Victoria soils which were dominated by the fast growing Rhizobiumsp. and Agrobacterium sp. and to a lesser extent Burkholderia sp. strains. [34] averaged the probable number of rhizobial populations in soils of different $\mathrm{pH}$ and observed the gradual reduction of fast growing groups of rhizobia as the $\mathrm{pH}$ was reducing while [35] observed an increase in the population of Bradyrhizobium as the $\mathrm{pH}$ decreased as was observed in this study. A few exceptions to this trend were noted within isolates identified as Rhizobia sp. and Agrobacteriumsp. which occurred in both the highly acidic and low P soils of Kisumu and Karungu as well as the moderately acidic and high $\mathrm{P}$ soils of Kendu bay and Port Victoria.

A remarkable outcome of this study was the occurrence of two Burkholderia strains (BAMKbay8 and BAMsp3) as Nfixing associates of bambara groundnuts, which was confirmed by highly effective and above twenty nodules per plant in the glasshouse plant tests. Isolate BAMKbay8 outperformed the commercial isolate USDA110 and nearly equalled the reference strain KFR 259 in symbiotic performance as shown in Table 3. The N-fixation ability of some members of the genus Burkholderia was first proposed by [36] and later confirmed by [37] and [38]. The 16S rRNA genes phylogeny of our two isolates depicted their close relations to Burkholderia tuberum strain DUS833 and $B$. phymatum strain JVNU IL24 with the former having been isolated from the root nodules of Aspalathus callosa in South Africa [39]. According to [40] the bambara groundnuts landraces cultivated in Kenya are of West and South African descent and were introduced into East African farming systems through Uganda and Tanzania. 
It is therefore plausible to argue that the $\mathrm{N}$-fixing Burkholderia strains found in this study may have been introduced together with the bambara germplasm during this period. Furthermore, the two isolates occurred in the soils of Port Victoria and Kendu bay which were active inter-border trading points through Lake Victoria. The absence of Burkholderia isolates from Kisumu and Karungu soils may be due to its preference to acidic soils as was observed in the isolates reaction on BTB. Bontemps and colleagues [41] confirmed the preference of Burkholderia sp. to acidic and low $\mathrm{N}$ soils in their study of the association of this group with Brazilian legumes.

We found the occurrence of Agrobacterium sp. in all soils tested indicating the high distribution of this group within the region although results of the plant tests showed only one isolate (BAMKbay1) produced effective nodules. Numerous studies comparing Agrobacterium and Rhizobium genera have been done which led [42] to propose merging the two genera based on similarity of $16 \mathrm{~S}$ rDNA genes. According to Bergey's Manual of Bacterial Systematics, there is no clear phenotypic distinction between the two groups which was evident in our study despite the phenotypic variation tests done. It was apparent that the Agrobacterium isolates did not absorb Congo red which is a basic discriminatory test for $\mathrm{N}$-fixing rhizobia against other soil microbes. It was however surprising to find isolate BAMKbay1 producing effective nodules since the $\mathrm{N}$-fixation ability of this genus is still disputed as this process is mediated by nif and nod genes which are absent in this group [43]. Thus, the effective nodules produced by BAMKbayl may have been as a result of acquisition of nif genes through lateral gene transfer from other groups which possess them naturally [44]. Since Agrobacterium sp. is an effective endophytic inducer of tumors in plant roots [45], it is possible that these pathogenic structures were transformed into useful nitrogen fixing agents after gaining the necessary genes. Alternatively, the isolate may have acquired both nif and nod genes which enabled it to produce the high number of nodules recorded. However, further PCR investigations are necessary on natural populations of Agrobacterium sp. in the soils of Lake Victoria basin to determine the occurrence of nif and nod genes.

Some of the most promising strains were BAMKis12, BAMKis8, BAMKis4 and BAMKar3 (Bradryrhizobium sp.) and BAMKbay8 and BAMsp3 (Burkholderia sp.) which produced highly effective nodules and high plant biomass values. These strains have potential use as bio-fertilizers in the production of bambara groundnuts although they were relatively not well distributed in the four soils used for isolation unlike isolates identified as Agrobacterium and Rhizobium which occurred in all the soils. Possibly, stiff competition for infection and nodulation amongst different strains may have favored the fast growing strains (Rhizobium and Agrobacterium) which are known to have better rates of competition for nodule occupancy [46]. Thus, bambara groundnuts is arguably more compatible with Bradyrhizobium and Burkholderia but are seemingly out-competed for nodule occupancy in the local soils by the less/ineffective Rhizobium and Agrobacterium respectively. Conversely, since competitive ability and nodule occupancy is influenced by the prevailing status of the media [35]; the near neutral $\mathrm{pH}$ of the vermiculite used in the glasshouse experiment may have impacted negatively on some of the acid tolerant strains. Based on the findings of this study, isolates BAMKis12, BAMKis8, BAMKis4, BAMKbay8 and BAMsp3 genetically characterized as Bradyrhizobium sp. and Burkholderia sp. respectively can potentially be used as biofertilizers in inoculation programmes to improve the productivity of bambara groundnuts in the region. Further investigations on their symbiotic performance under natural conditions might reveal the actual symbiotic preferences of bambara groundnuts, and confirm the effect of inoculation on plant yield factors.

\section{CONCLUSIONS}

This study revealed high levels of heterogeneity within resident bambara groundnut rhizobium populations in the soils of Lake Victoria basin. Our findings under controlled conditions showed better competence of indigenous strains compared to the market available commercial strain USDA110. Field inoculation trials and tests on competition for nodule occupancy are needed to evaluate the potential of this abundant genetic resource for sustainable production of the under-utilized bambara groundnuts which can supply alternative sources of nutrient rich diets to resource poor farmers in the region.

\section{ACKNOWLEDGEMENTS}

Field and glass house experiments were sponsored by Kenya National Commission for Science, Technology and Innovation through a NACOSTI PhD grant to Benson Onyango. Jaramogi Oginga Odinga University of Science and Technology is acknowledged for providing laboratory space and experimental fields for conducting the initial trials by the support of John Odero. Molecular analysis was done at the BecA-ILRI Hub following an award of the African Bioscience Challenge Fund (ABCF) to Benson Onyango. Glasshouse symbiotic evaluation experiments were done at Kenya Forestry Research Institute headquarters at Muguga with technical assistance from Charles Magare and Emmanuel Makatiani. We are grateful to Dr. Odee D. W for critically reviewing this manuscript.

\section{REFERENCES}

1. Sprent J. Nodulation in legumes. Kew, UK: Kew Publishing; 2001. p 156-157.

2. Chen W. M, Moulin L., Bontemps, C., Vandamme P., Bena G. and Boivin-Masson C. Legume symbiotic nitrogen fixation by beta-proteobacteria is wide spread in nature. Journal of Bacteriology. 2003; 185: 7266-7272.

3. Mclean A. M., Finan T. M. and Sadowsky M. J. Genomes of the symbiotic nitrogen-fixing bacteria of the legumes. Plant Physiology. 2007; 144:615-622.

4. Dai J., Liu X. and Wang Y. Genetic diversity and phylogeny of rhizobium isolated from Caraganamycrophylla growing in desert soils in Ningxia China. Genetic and Molecular Research. 2012; 11(3): $2683-2693$. 
5. Mothapo N.V., Grossman J. M., Maul J. E., Shi W. and Isleib T. Genetic diversity of resident soil rhizobia isolated from nodules of distinct hairy vetch (Viciavillosa Roth) genotypes. Applied Soil Ecology. 2013; 64: 201 - 213.

6. Azam-Ali S. N., Sesay A., Karikari S. K., Massawe F. J., Aguitar-Manjarrez J., Bannayan M. and Hampson K. J. Assessing the potential of under-utilized crops: A case study using Bambara groundnut. Experimental Agriculture. 2001; 37: 433-472.

7. Sprent J. I., Odee D. W and Dakora F. T. African legumes: A vital but under-utilized resource. Journal of Experimental Botany. 2010; 61 (5): 1257 - 1265.

8. Mkandawire C. H. Review of Bambara groundnuts [Vigna subterranean (L.) Verdc.] production in Sub Saharan Africa. Agriculture Journal. 2007; 2(4): 464 - 470.

9. Jaetzold R., Schmidt H., Hortnez B. and Shisanya C. Ministry of Agriculture: Farm management handbook of Kenya Vol. 2 Natural conditions and farm management information. $2^{\text {nd }}$ Edtn Part A. West Kenya (Nyanza province). 2007; p. $1-81$.

10. Doku E. V. and Karikari S. K. Bambara groundnut. Economic Botany. 1971; 25: 225 - 262.

11. Gueye M., James E. K., Kierars M. and Sprent J. I. The development and structure of root nodules on bambara groundnuts [Voandzeia (Vigna) subterranea]. World Journal of Microbiology and Biotechnology. 1998; 4(3): 365-375.

12. Kanu S. A. and Dakora F. D. Symbiotic nitrogen contribution and biodiversity of bacteria nodulating Psoralea species in the Cape Fynbos of South Africa. Soil Biology and Biochemistry. 2012; 54:68-76.

13. Mohale C. K., Belane A. K. and Dakora F. D. Why is bambara groundnut able to grow and fix $\mathrm{N}_{2}$ under contrasting soil conditions in different agroecologies? A presentation at the $3^{\text {rd }}$ international scientific conference on neglected and underutilized species on $26^{\text {th }}$ September, 2013 in Accra Ghana. 2013; p. 13-16.

14. Graham, P. H. Ecology of root nodule bacteria. In: Dilworth M. J., James E. K., Sprent I. J., and Newton E. W. (Eds), Nitrogen fixing leguminous symbioses. Springer Science+Business Media B. V., Dordrecht, Netherlands. 2008; pp 23 - 43.

15. Anyango B., Wilson K. J., Beynon J. L. and Giller K. E. Diversity of rhizobia nodulating Phaseolus vulgaris L. in two Kenyan soils with contrasting pHs. Applied Environmental Microbiology. 1995; 61:4016-4021.

16. Chemining'wa G. and Vessey J. The abundance and efficacy of Rhizobium leguminosarum bv. viciae in cultivated soils of the eastern Canadian prairie. Soil Biology and Biochemistry. 2006; 38: 294-302.

17. Prevost D., Drouin P., Laberge S., Bertrand, A., Cloutier, J. and Levesque, G. Cold-adapted rhizobia for nitrogen fixation in temperate regions. Canadian Journal of Botany. 2003; 81:11531161.

18. Anderson J. M. and Ingram J. S. I. Tropical soil biology and fertility: A handbook of methods, $2^{\text {nd }}$ edtn, CAB International, Wallingford, UK. 1993; P 85-93.

19. Giller K.E. Nitrogen fixation in tropical cropping systems. $C A B$ International, Wallingford U.K. 2001; p. 423.

20. Bray R.H., and Kurtz L.T. Determination of total nitrogen, organic and available forms of phosphorus in soils. Soil Science. 1945; 59: 39 - 45.

21. Lindsay W. L. and Norvell W. A. Development of a DTPA soil test for zinc, iron, manganese and copper. Soil Science Society of America Journal. 1978; 42: 421-428.

22. Bala, A. Collection and maintenance of elite rhizobial strains: Milestone reference number 3.2.1 $\left(\mathrm{N}_{2}\right.$ Africa: Putting Nitrogen fixation to work in smallholder farmers in Africa). www.N2Africa.org.

23. Woomer P. L., Karanja N., Kisamuli S. M., Murwira M. and Bala, A. A revised manual for rhizobium methods and standard protocols available in the project website: Milestone reference number 5.5.1 In: N2Africa: Putting Nitrogen fixation to work in smallholder farmers in Africa: www.N2Africa.org.

24. Eden P. A, Schmidt T. M, Blakemore R. P, Pace N. R Phylogenetic Analysis of Aquaspirillum magnetotacticum Using Polymerase Chain Reaction-Amplified 16S rRNA-Specific DNA. International Journal of Systematic Bacteriology. 1991; 41 (2): 324-325.

25. Jiang H., Dong H., Zhang G., Yu B., Chapman L. R. and Fields M. W. Microbial diversity in water and sediment of Lake Chaka, an Athalassohaline Lake in Northwestern China. Applied and Environmental Microbiology. 2006; 72 (6): 3832-3845.

26. Tamura K., Peterson D., Peterson N., Stecher G., Nei M., and Kumar S. MEGA6: Molecular evolutionary genetics analysis using maximum likelihood, evolutionary distance, and maximum parsimony methods. Molecular Biology and Evolution. 2011; 28: 2731-2739.

27. Tamura K. M., and Kumar S. Prospects for inferring very large phylogenies by using the neighbor-joining method. Proceedings of the National Academy of Sciences (USA). 2004; 101:1103011035 .

28. Lafay B. and Burdon J. J. Molecular diversity of rhizobia nodulating the invasive legume Cytisuss coparius in Australia. Journal of Applied Microbiology. 2006; 100: 1228-1238.

29. Mierzwa B., Wdowiak-Wróbel S. and Malek W. Robinia pseudoacacia in Poland and Japan is nodulated by Mesorhizobium amorphae strains. Antonie van Leeuwenhoek. 2010; 97: 351-361.

30. Ulrich, A. \& Zaspel, I. Phylogenetic diversity of rhizobial strains nodulating Robinia pseudoacacia L. Microbiology. 2000; 146:2997-3005

31. Moschetti G., Peluso A., Protopapa A., Anastasio M., Pepe O. and Defez R. Use of nodulation pattern, stress tolerance, nodC gene amplification, RAPD-PCR and RFLP-16S rDNA analysis to discriminate genotypes of Rhizobium leguminosarum biovarviciae. Systematic and Applied Microbiology. 2005; 28: 619-631.

32. Martinez-Romero, E. Diversity of Rhizobium-Phaseolus vulgaris symbiosis: Overview and perspectives. Plant Soil. 2003; 252:1123.

33. Brockwell J., Pilka A. and Holliday R.A. Soil pH is a major determinant of the numbers of naturally occurring Rhizobium meliloti in non-cultivated soils in central New South Wales. Australian Journal of Experimental Agriculture. 1991; 31: 211219.

34. Slattery J. F., Pearce D. J., and Slattery W. J. Effects of resident rhizobial communities and soil type on the effective nodulation of pulse legumes. Soil Biology and Biochemistry. 2004; 36: 1339 $-1346$.

35. Moulin L., Chen W. M., Béna G., Dreyfus B., and BoivinMasson C. Rhizobia: The family is expanding. In: Nitrogen Fixation; Global perspectives. T. Finan, M. O’Brian, D. Layzell, K. Vessey and W. Newton. (Edts). CAB International. 2002; pp. 61-65.

36. Vandamme P., Goris J., Chen W. M., de Vos P. and Willems A. Burkholderia tuberum sp. nov. and Burkholderia phymatum sp.nov., nodulate the roots of tropical legumes. Systematic and Applied Microbiology. 2002; 25: 507-512.

37. Chen W. M., James E. K., Chou J. H., Sheu S. Y., Yang S. Z. and Sprent, J. I. beta-Rhizobia from Mimosapigra, a newly 
discovered invasive plant in Taiwan. New Phytologist. 2005; 168: 661-675.

38. Elliott G. N., Chen W. M., Chou J. H., Wang H. C., Sheu S. Y., Perin L., Reis M. V., Moulin L., Simon M. F., Bontemps C., Sutherland J. M., Bessi R., Faria S. M., Trinick M. J., Prescott A. R., Sprent J. I. and James E. K. Burkholderia phymatum is a highly effective nitrogen-fixing symbiont of Mimosa spp. and fixes nitrogen ex planta. New Phytologist. 2007; 173: $168-180$.

39. Ngugi G.W. Promoting the conservation and use of underutilized and neglected crops; A case study of Kenya. In: Bambara groundnut (Vigna subterranea L. Verdc.): Proceedings of the workshop on conservation and improvement of bambara groundnuts (Vigna subterranea L. Verdc.). Harare, Zimbabwe. Heller J. F. Begemann and Mushoga J. Edtrs. 1997; pp 84-112.

40. Bontemps C., Elliott G. N., Simon M. F., Dos Reis Junior F. B., Gross E., Lawton R. C., Neto N. E., de Fatima Loureiro M., De Faria S. M. Burkholderia species are ancient symbionts of legumes. Molecular Ecology. 2010; 19: 44-52.

41. Young J. M., Kuykendall L. D., Martinez-Romero E., Kerr A. and Sawada H. A revision of Rhizobium (Frank, 1889), with an emended description of the genus and the inclusion of all species of Agrobacterium (Conn, 1942) and Allorhizobium undicola (de Lajudie et al., 1998) as new combinations: Rhizobium radiobacter, R. rhizogenes, $R$. rubi, R. undicola and $R$. vitis. International Journal of Systematic and Evolutionary Microbiology. 2001; 5: 89-103.
42. Lindstrom K. and Young J. P. W. International committee on systematics of prokaryotes; Sub-committee on the taxonomy of Rhizobium and Agrobacterium. International Journal of Systematic and Evolutionary Microbiology. 2011; 61: 3089 3093.

43. Dilworth M. J., Howieson J. G., Reeve W. G., Tiwari R. P., and Glenn A. R. Acid tolerance in root nodule bacteria and selecting for it. Australian Journal of Experimental Agriculture. 2001; 41: 435-446.

44. Wang L. L., Wang E. T., Liu J., Li Y. and Chen W. X. Endophytic occupation of root nodules and roots of Melilotus dentatus by Agrobacterium tumefaciens. Microbiology and Ecology. 2006; 52: 436-443.

45. Howieson J. G., O'Hara G. W. and Carr S. J. Changing roles for legumes in Meditteranean Agriculture: Developments from an Australian perspective. Field Crops Research. 2000; 65: 107-122.

\section{How to cite this article:}

Onyango BO, Koech PK, Anyango B, Nyunja RA, Skilton RA, Stomeo F. Morphological, genetic and symbiotic characterization of root nodule bacteria isolated from Bambara groundnuts (Vigna subterranea L. Verdc) from soils of Lake Victoria basin, western Kenya. J App Biol Biotech. 2015; 3 (01): 001-010. 